\title{
CORRELATION BETWEEN FINDINGS IN MAGNETIC RESONANCE AND BIOPSY IN THE DIAGNOSIS OF SPONDYLODISCITIS
}

\author{
CORRELAÇÃO ENTRE ACHADOS NA RESSONÂNCIA MAGNÉTICA E A BIÓPSIA NO \\ DIAGNÓSTICO DE ESPONDILODISCITE
}

\section{CORRELACIÓN ENTRE HALLAZGOS EN LA RESONANCIA MAGNÉTICA Y LA BIOPSIA EN EL DIAGNÓSTICO DE ESPONDILODISCITIS}

\author{
Gustavo lucio Babbosa de Quelroz, Eloy de Avila Fernandes, ${ }^{2}$ André Sousa Garci, Igor Pelluccl Pinto, ${ }^{1}$ Gabriel Paris de Godor, \\ Renato Hiroshi Salvion Ueta, ${ }^{3}$ Eduardo Barros Puettas, ${ }^{3}$ Adriana Macedo Dell'Aoulia ${ }^{4}$ \\ 1. Universidade Federal de São Paulo, Department of Orthopedics and Traumatology, São Paulo, SP, Brazil. \\ 2. Universidade Federal de São Paulo, Department of Image Diagnostics, São Paulo, SP, Brazil. \\ 3. Universidade Federal de São Paulo, Department of Orthopedics and Traumatology, Spinal Pathology Group, São Paulo, SP, Brazil. \\ 4. Universidade Federal de São Paulo, Department of Orthopedics and Traumatology, Department of Medicine/Infectology Course of Study, São Paulo, SP, Brazil.
}

\begin{abstract}
Objective: To correlate magnetic resonance imaging (MRI) findings with the microbiological and anatomopathological diagnosis of spinal infection Methods: A retrospective, cohort review of online medical records (laboratory, anatomopathology and diagnostic imaging sector) of patients diagnosed with spondylodiscitis, who underwent a full spine MR scan between January 2014 and July 2018 at the Department of Orthopedics and Traumatology of the Universidade Federal de São Paulo. Results: Staphylococcus aureus was the most commonly found etiological agent (57\%). Blood culture was positive in $76 \%$ of cases and $82 \%$ of the patients who underwent biopsy had a spondylodiscitis diagnosis. Pain was the most prevalent clinical symptom and the lumbosacral spine was the most frequent site of infection. T1 hyposignal, T2/STIR hypersignal, and terminal plate destruction were verified in almost all MR scans. Conclusions: No direct correlation was found between MR findings and any specific etiological agent. Blood culture and biopsy are important diagnostic tools that should be used for accurate diagnosis of the infectious agent. Level of evidence IV; Diagnostic Study.
\end{abstract}

Keywords: Discitis; Magnetic Resonance Imaging; Biopsy; Spine; Blood Culture.

\section{RESUMO}

Objetivo: Correlacionar os achados de ressonância magnética (RNM) com o diagnóstico microbiológico e anatomopatológico de infecção na coluna vertebral. Métodos: Estudo de coorte retrospectivo de revisão de prontuários online (laboratório, anatomopatológico e setor de diagnóstico por imagem) de pacientes com diagnóstico de espondilodiscite, submetidos ao exame de RNM da coluna vertebral e acompanhados pelo Departamento de Ortopedia e Traumatologia da Universidade Federal de São Paulo, entre janeiro de 2014 e julho de 2018. Resultados: O agente etiológico mais comum encontrado foi o S. aureus (57\%). A hemocultura mostrou-se positiva em $76 \%$ dos casos e $82 \%$ dos pacientes submetidos à biópsia apresentaram diagnóstico de espondilodiscite. A dor foi o achado clínico mais prevalente e a coluna lombossacra foi o sítio mais frequente de infecção. No exame de RNM, a presença de hipossinal em T1, hipersinal em T2/STIR e destruição das placas terminais foram identificados em quase todos os casos. Conclusões: Não houve correlação direta dos achados na RNM com um agente etiológico específico na espondilodiscite. A hemocultura e a biópsia são ferramentas diagnósticas importantes que devem ser utilizadas para o diagnóstico preciso do agente infeccioso. Nível de evidência IV; Estudo diagnóstico.

Descritores: Discite; Imagem por Ressonância Magnética; Biópsia; Coluna Vertebral; Hemocultura.

\section{RESUMEN}

Objetivo: Correlacionar los hallazgos de resonancia magnética (RNM) con el diagnóstico microbiológico y anatomopatológico de infección de la columna vertebral. Métodos: Un estudio de cohorte retrospectivo de revisión de prontuarios en línea (laboratorio, anatomopatológico y sector de diagnóstico por imagen) de pacientes con diagnóstico de espondilodiscitis, sometidos al examen de RNM de la columna vertebral y acompañados por el Departamento de Ortopedia y Traumatología de la Universidad Federal de São Paulo, entre enero de 2014 y julio de 2018. Resultados: El agente etiológico más común encontrado fue el S. aureus (57\%). El hemocultivo se mostró positivo en $76 \%$ de los casos y $82 \%$ de los pacientes sometidos a biopsia presentaron diagnóstico de espondilodiscitis. El dolor fue el hallazgo clínico más prevalente y la columna lumbosacra fue el sitio más frecuente de infección. En el examen de RNM, la presencia de hiposeñal en T1, hiperseñal en T2/ STIR y destrucción de las placas terminales fueron identificadas en casi todos los casos. Conclusiones: No hubo correlación directa de los hallazgos de la RNM con un agente etiológico especifico en la espondilodiscitis. El hemocultivo y la biopsia son herramientas diagnósticas importantes, que deben ser utilizadas para el diagnóstico preciso del agente infeccioso. Nivel de evidencia IV; Estudio Diagnóstico.

Descriptores: Discitis; Imagen por Resonancia Magnética; Biopsia; Columna Vertebral; Cultivo de Sangre.

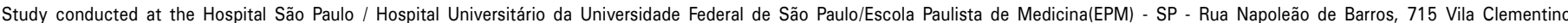
CEP: 04024-002 São Paulo -SP

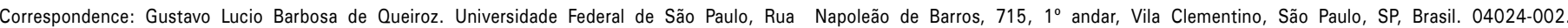
gustavoobarbosa@hotmail.com 


\section{INTRODUCTION}

Spondylodiscitis is a condition that can affect one or more spinal structures and segments and be caused by bacteria, fungi, or parasites. ${ }^{1-5}$ It usually affects the intervertebral disc and the vertebral body. ${ }^{1,2}$

Early diagnosis and identification of the specific etiologic agent are crucial to correct treatment and prevention of neurological deficit and spinal deformities. ${ }^{1,6}$ The most commonly found agent, in more than $50 \%$ of cases, is Staphylococcus aureus. ${ }^{1,7-10}$ Early detection of this infection continues to be a challenge.

Two major criteria are essential to establishing the diagnosis of pyogenic spondylodiscitis: the presence of an image characteristic of spinal infection and the isolation of the agent through hemoculture or culture of the affected site. ${ }^{11,12}$

Magnetic resonance imaging (MRI) is the imaging method with the highest sensitivity (93-96\%) and specificity (92.5-97\%) for an early diagnosis of spondylodiscitis. $7,8,13,14$

Several MRI characteristics have been described for the diagnosis of spondylodiscitis and spinal osteomyelitis, for example, a low-intensity signal in the T1-weighted sequence and a high-intensity signal in the T2-weighted sequence. In spondylodiscitis, we may also observe destruction of at least one spinal terminal plate, loss of disc height, and formation of a paraspinal abscess. ${ }^{7,15-17}$ The objective of this study is to correlate the MRI findings with the specific agents that cause the spinal infection.

\section{METHODS}

The study was conducted at the Hospital Universitário da Universidade Federal de São Paulo (UNIFESP), one of the references for the treatment of spinal pathologies in the state of São Paulo. It was submitted to and approved by the Institutional Review Board (CAAE: 00483618.7.0000.5505). The Informed Consent Form was not required to be filled out by the patients since it was waived by the Institutional Review Board.

The study was classified as a retrospective, descriptive cohort review of online medical records (clinical, microbiology laboratory, anatomopathological, and diagnostic imaging sector data) of patients with spondylodiscitis who were treated by the Spine and Osteoarticular Infection Group of the Department of Orthopedics and Traumatology (DOT) of UNIFESP during the period from January 2014 to July 2018

The spinal MR scans of adult patients with suspected infection were analyzed by two independent observers at different times. The first observer was an MD Radiologist (EAF) with more than 20 years of experience in the musculoskeletal area of the Diagnostic Imaging Department (DDI) of the Escola Paulista de Medicina (EPM)/ UNIFESP and the second observer (GLBQ), a physician specializing in spinal pathology from the Department of Orthopedics and Traumatology (DOT).

Training for the radiologist (EAF) and the orthopedist (GLBQ) was conducted using 10 cases in order to standardize the reading of the examinations. The images of the examinations were evaluated without access to any information that identified the patients, that is, they were anonymous.

Initially, each doctor assessed the presence in the vertebral bodies of a marked hyposignal in T1, a hypersignal in T2 with fat suppression or STIR, the presence or absence of terminal plate destruction, the loss or not of disc height, the presence or absence of liquid in the intervertebral disc, and the presence or absence of paraspinal abscess.

The level of discordance between the observers was not statistically significant using the McNemar method. Due to the greater experience of Observer 1 , their analysis was considered in preference to that of Observer 2.

Each MR image finding was correlated with the clinical, microbiological, and anatomopathological patient data. The information obtained was organized in tables and graphs with the clinical, laboratory, and imaging correlation. The statistical analysis was performed using Microsoft Excel ${ }^{\circledR}$ and Stata ${ }^{\circledR}$ software.

\section{RESULTS}

Twenty-one patients were allocated to the study, ranging in age from 29 to 82 years, with a mean age of 55 years and a median age of 57 years. Of these, 14 (67\%) were male and 7 (33\%) were female.

The spondylodiscitis diagnosis was confirmed through histopathology and/or culture (hemoculture or bone fragment biopsy). Only $4(19 \%)$ of the patients were not submitted to biopsy. Among the biopsied patients, 14 (82\%) had a positive culture and a biopsy report suggestive of infection and only 3 did not have the diagnosis confirmed by the culture or by anatomopathology. The blood culture was positive in $76 \%$ of cases, Staphylococcus aureus being the most prevalent germ at $57 \%$, followed by coagulase-negative Staphylococcus (CoNS) at $18 \%$ and $M$. tuberculosis at $13 \%$. (Figure 1)

Regarding symptomology, 12 (57\%) manifested fever and weight loss. Prostration was present in 10 patients (48\%), anorexia in 7 (33\%), night sweats in 5 (24\%), and more than half (62\%) had some sort of associated comorbidity. All patients analyzed complained of pain. (Figure 2)

Topographically, the lumbosacral spine is the most frequent location, (Figure 3) and the most affected vertebral body was L3, in 15\% of cases. We also observed that intervertebral discs L2L3 (20.8\%) and L3L4 (16.7\%) were the most affected by the infection. The presence of paravertebral phlegmon was found in $40 \%$ of cases in the lumbosacral region, $33 \%$ of cases in the thoracolumbar region, $23 \%$ of cases in the thoracic region, and $4 \%$ of cases in the cervical region.

In the first observer's radiological analysis, $100 \%$ of cases presented a marked hyposignal in $\mathrm{T} 1$ in the vertebral body and destruction of the terminal plates. Only $11(52 \%)$ had loss of disc height and $15(71 \%)$ showed the presence of liquid in the intervertebral disc. (Table 1) In the weighted T2/STIR image, 90\% had a hypersignal in the vertebral body. The presence of a paraspinal abscess was identified in 9 cases (43\%), with similar incidence in the thoracolumbar and lumbosacral regions (44\%). It was only possible to correlate the images with the isolated etiological agent $S$. aureus, due to the lower number of other isolated agents. (Table 2)

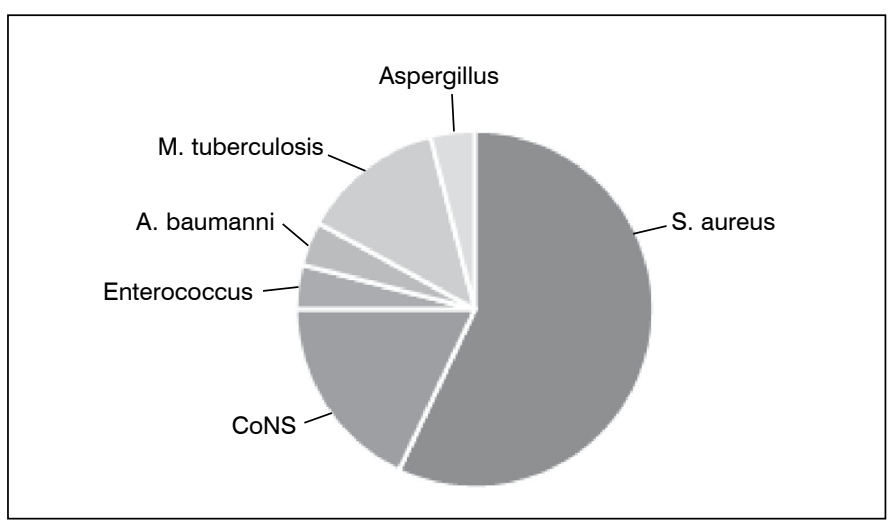

Figure 1. Microbiological agents isolated in the hemoculture of patients with spondylodiscitis during the period from January 2014 to July 2018 at EPM/UNIFESP.

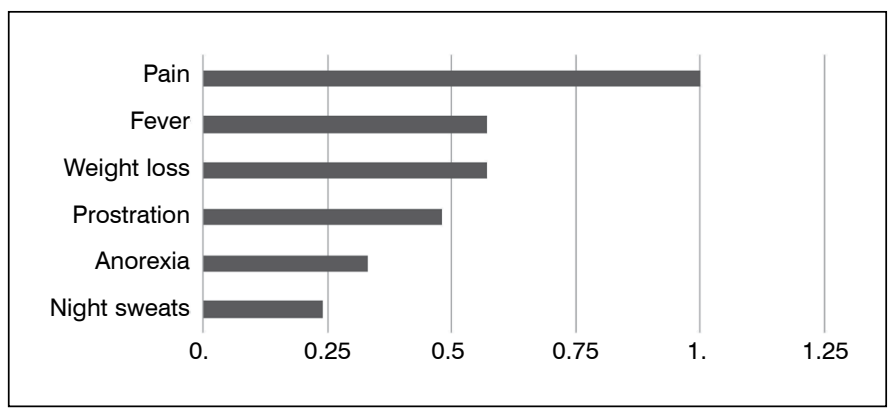

Figure 2. Symptomatology of the patients with spondylodiscitis from January 2014 to July 2018 at EPM/UNIFESP. 


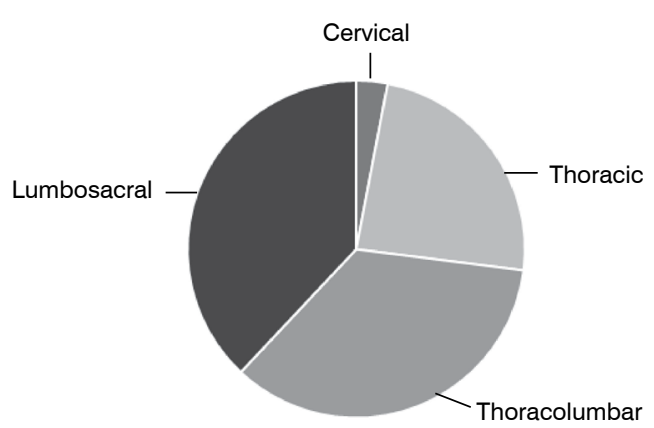

Figure 3. Location of spondylodiscitis during the period from January 2014 to July 2018 at EPM/UNIFESP.

Table 1. Correlation of the imaging findings of spondylodiscitis.

\begin{tabular}{l|c|c|c|c|c|c}
\hline Coluna1 & $\begin{array}{c}\text { Hypo } \\
\text { T1 }\end{array}$ & $\begin{array}{c}\text { Destruction of } \\
\text { the Terminal } \\
\text { Plate }\end{array}$ & $\begin{array}{c}\text { Loss } \\
\text { of Disc } \\
\text { Height }\end{array}$ & $\begin{array}{c}\text { Presence } \\
\text { of Liquid in } \\
\text { the Disc }\end{array}$ & $\begin{array}{c}\text { Hyper } \\
\text { T2/ } \\
\text { STIR }\end{array}$ & $\begin{array}{c}\text { Paraspinal } \\
\text { Abscess }\end{array}$ \\
\hline All agents & $100 \%$ & $100 \%$ & $52 \%$ & $71 \%$ & $90 \%$ & $43 \%$ \\
\hline
\end{tabular}

Table 2. Correlation of the imaging findings of spondylodiscitis with S. aureus isolated in the culture.

\begin{tabular}{c|c|c|c|c|c|c}
\hline Coluna1 & $\begin{array}{c}\text { Hypo } \\
\text { T1 }\end{array}$ & $\begin{array}{c}\text { Hyper } \\
\text { T2 }\end{array}$ & $\begin{array}{c}\text { Destruction } \\
\text { of the } \\
\text { Terminal } \\
\text { Plate }\end{array}$ & $\begin{array}{c}\text { Presence } \\
\text { of } \\
\text { Abscess }\end{array}$ & $\begin{array}{c}\text { Loss of } \\
\text { Disc Height }\end{array}$ & $\begin{array}{c}\text { Presence of } \\
\text { Liquid in the } \\
\text { Disc }\end{array}$ \\
\hline S. aureus & $\begin{array}{c}13 \\
(100 \%)\end{array}$ & $\begin{array}{c}12 \\
(92 \%)\end{array}$ & $13(100 \%)$ & $3(23 \%)$ & $6(46 \%)$ & $10(77 \%)$ \\
\hline
\end{tabular}

\section{DISCUSSION}

Considering that the etiological diagnosis of the spondylodiscites is not always obtained through hemoculture, we often must use invasive and complex methods. Therefore, it is extremely important to use other tools that enable the diagnosis. Gouliouris et al. ${ }^{8}$ reported that although hemoculture is a simple and low-cost method achieving a diagnosis in $40-60 \%$ of cases, biopsy, which follows as the gold standard, can be performed for diagnostic confirmation. In our study, blood culture positivity was $76 \%$, a value higher than that found in the literature, which might be explained by the stage of the disease (more advanced) in the patients at the time of hospital treatment, given that the study was conducted in a tertiary center.

In this study, Staphylococcus aureus was found in more than $50 \%$ of the cases and identified as the most prevalent microbiological agent, corroborating other studies in the literature. ${ }^{1,7-10}$ Although this agent was defined as pyogenic, we found a low correlation with the formation of the paraspinal abscess.

The presence of a paraspinal abscess was identified in less than $50 \%$ of the cases of pyogenic spondylodiscitis, though the observers found it in only $23 \%$ of the MR scans of patients with a microbiological diagnosis of $S$. aureus. In their study, Jung et al. ${ }^{14}$ showed that although the presence of a paraspinal abscess is much more often encountered in granulomatous infections (95\%), pyogenic infection caused by bacteria is responsible for at least $50 \%$ of cases of abscess formation.

MRI can provide high diagnostic accuracy, proving its superiority over other imaging examinations. ${ }^{1,9,11,13}$ Arbelaez et al. ${ }^{1}$ considered sensitivity, specificity, and accuracy above $90 \%$ in their study and positioned it as the method of choice for the successful identification of possible spondylodiscitis. This examination, however, is not a good method for routine follow-up. ${ }^{13}$ Through T1- and T2-weighted sequences, it is possible to identify disorders of the vertebral bodies, loss of disc height, presence of paraspinal abscesses and masses, as observed in several studies. ${ }^{1,7,9,13} \mathrm{We}$ observed a strong correlation between the radiological findings and the laboratory and anatomopathological findings that confirm the spondylodiscitis diagnosis.

The clinical presentation of spondylodiscitis is often non-specific and insidious, making diagnosis difficult.11,13,18 As observed in our study and by most authors, spinal pain is the most important symptom for clinical diagnosis of spondylodiscitis. ${ }^{5,8,10,13}$ Fever is not always present; we found it in only $57 \%$ of cases. Prodi et al. ${ }^{5}$ and Diehn ${ }^{13}$ consider this symptom relatively common, but inconsistent. Gouliouris et al. ${ }^{8}$ identified the presence of fever in approximately $50 \%$ of cases.

In terms of location, we observed most of the infections to occur in the lumbar region, results like those of Malawski SK et al. ${ }^{19}$ and Mylona $\mathrm{E}$ et al. ${ }^{20}$ followed by the thoracic and cervical regions, in descending order of prevalence. Only one study ${ }^{21}$ analyzed reported the cervical region as the most frequent site of pyogenic infection in the spine.

There was a higher number of suspected cases of spondylodiscitis among patients treated at the service, however, the noninclusion of cases that did not have a positive culture and/or an anatomopathological biopsy collection, respecting our exclusion criteria, resulted in a reduction in the number of selected and allocated patients, which became a limitation of our study.

\section{CONCLUSION}

There was no direct correlation between the MRI findings and a specific etiological agent in spondylodiscitis. Even changes such as paraspinal abscess and collections had a weak correlation with a pyogenic agent, such as Staphylococcus aureus. Nevertheless, the examination enables early diagnosis of spinal infections.

Even though pyogenic spondylodiscitis presents characteristic findings in MRI examinations it is still a challenge to determine the etiological agent using only this imaging method. Hemoculture and biopsy are important diagnostic tools and should be used for the accurate diagnosis of the infectious agent.

All authors declare no potential conflict of interest related to this article.

CONTRIBUTION OF THE AUTHORS: Each author made significant individual contributions to the manuscript. GLBQ: main author; ASG, IPP, EAF and AMDA: project structure, statistical analysis, bibliographical research, and preparation of the article; GLBQ and EAF: evaluation of the magnetic resonance images; GPG, DDC, RHSU, and EBP: data tabulation, literature and article review.

\section{REFERENCES}

1. Arbelaez A, Restrepo F, Castillo M. Spinal infections: clinical and imaging features. Top Magn Reson Imaging. 2014;23(5):303-14.

2. Rutges JP, Kempen DH, van Dijk M, Oner FC. Outcome of conservative and surgical treatment of pyogenic spondylodiscitis: a systematic literature review. Eur Spine J. 2016;25(4):983-99

3. Foreman SC, Schwaiger BJ, Meyer B, Gersing AS, Zimmer C, Gempt J, et al. Computed Tomography and Magnetic Resonance Imaging Parameters Associated with
Poor Clinical Outcome in Spondylodiscitis. World Neurosurg. 2017;104:919-26.e2. 4. Foreman SC, Schwaiger BJ, Gempt J, Jungmann PM, Kehl V, Delbridge C, et al. MR and CT Imaging to Optimize CT-Guided Biopsies in Suspected Spondylodiscitis. World Neurosurg. 2017;99:726-34.e7.

5. Prodi E, Grassi R, lacobellis F, Cianfoni A. Imaging in Spondylodiskitis. Magn Reson Imaging Clin N Am. 2016;24(3):581-600.

6. Leone A, Dell'Atti C, Magarelli N, Colelli P, Balanika A, Casale R, et al. Imaging of spondylodiscitis. Eur Rev Med Pharmacol Sci. 2012;16 Suppl 2:8-19. 
7. Go JL, Rothman S, Prosper A, Silbergleit R, Lerner A. Spine infections. Neuroimaging Clin N Am. 2012;22(4):755-72.

8. Gouliouris T, Aliyu SH, Brown NM. Spondylodiscitis: update on diagnosis and management J Antimicrob Chemother. 2010;65 Suppl 3:Ill11-24.

9. Chen TY, Wu TC, Tsui YK, Chen HH, Lin CJ, Lee HJ, et al. Diffusion- Weighted Magnetic Resonance Imaging and Apparent Diffusion Coefficient Mapping for Diagnosing Infectious Spondylodiscitis: A Preliminary Study. J Neuroimaging. 2015;25(3):482-7.

10. Friedman JA, Maher CO, Quast LM, McClelland RL, Ebersold MJ. Spontaneous disc space infections in adults. Surg Neurol. 2002;57(2):81-6.

11. Kasalak Ö, Adams HJA, Jutte PC, Overbosch J, Dierckx RAJO, Wouthuyzen-Bakker M, et al. Culture yield of repeat percutaneous image-guided biopsy after a negative initial biopsy in suspected spondylodiscitis: a systematic review. Skeletal Radiol. 2018;47(10):1327-35.

12. Gasbarrini A, Boriani L, Salvadori C, Mobarec S, Kreshak J, Nanni C, et al. Biopsy for suspected spondylodiscitis. Eur Rev Med Pharmacol Sci. 2012:16 Suppl 2:26-34.

13. Diehn FE. Imaging of spine infection. Radiol Clin North Am. 2012;50(4):777-98.

14. Jung NY, Jee WH, Ha KY, Park CK, Byun JY. Discrimination of tuberculous spondylitis from pyogenic spondylitis on MRI. AJR Am J Roentgenol. 2004;182(6):1405-10.
15. Stäbler A, Reiser M. Imaging of spinal infection. Radiol Clin North Am. 2001;39(1):115-35.

16. Yeom JA, Lee IS, Suh HB, Song YS, Song JW. Magnetic Resonance Imaging Findings of Early Spondylodiscitis: Interpretive Challenges and Atypical Findings. Korean J Radiol. 2016;17(5):565-80

17. Patel KB, Poplawski MM, Pawha PS, Naidich TP, Tanenbaum LN. Diffusion-weighted MRI "claw sign" improves differentiation of infectious from degenerative modic type 1 signal changes of the spine. AJNR Am J Neuroradiol. 2014;35(8):1647-52.

18. Smids C, Kouijzer IJ, Vos FJ, Sprong T, Hosman AJ, de Rooy JW, et al. A comparison of the diagnostic value of MRI and 18F-FDG-PET/CT in suspected spondylodiscitis. Infection. 2017;45(1):41-9.

19. Malawski SK, Lukawski S. Pyogenic infection of the spine. Clin Orthop Relat Res. $1991 ;(272): 58-66$

20. Mylona E, Samarkos M, Kakalou E, Fanourgiakis P, Skoutelis A. Pyogenic vertebral osteomyelitis: a systematic review of clinical characteristics. Semin Arthritis Rheum. 2009;39(1):10-7.

21. Galhotra RD, Jain T, Sandhu P, Galhotra V. Utility of magnetic resonance imaging in the differential diagnosis of tubercular and pyogenic spondylodiscitis. J Nat Sci Biol Med. 2015;6(2):388-93. 